\title{
MINERALS AS A SOURCE OF NOVEL Li-ION BATTERY ELECTRODE MATERIALS
}

\author{
Anti Liivat, Josh Thomas* \\ Angström Advanced Battery Centre, Department of Chemistry, Uppsala University, Box 538, \\ SE-751 21 Uppsala, Sweden \\ *josh.thomas@kemi.uu.se
}

\begin{abstract}
As a tribute to the major contribution made by Academician Gligor Jovanovski to the field of Mineralogy in Macedonia, this paper promotes the potential role that minerals can have as a future source of inspiration in identifying novel materials for sustainable energy storage in general, and for advanced Li-ion batteries in particular. We exemplify this by indicating the innovative use of polyanions in novel $\mathrm{Li}$-ion battery cathode materials such as the olivine lithium iron phosphate $\left(\mathrm{LiFePO}_{4}\right)$, and in an even newer material - the orthosilicate lithium iron silicate $\left(\mathrm{Li}_{2} \mathrm{FeSiO}_{4}\right)$. Both materials have strong intrinsic links to mineralogy - and illustrate well how mineralogy can lead to new material breakthroughs in this and other areas of modern technology.
\end{abstract}

Keywords: minerals; Li-ion battery; electrodes; cathodes

\section{МИНЕРАЛИТЕ КАКО ИЗВОР НА НОВИ МАТЕРИЈАЛИ ЗА ЕЛЕКТРОДИ НА ЛИТИУМСКИТЕ БАТЕРИИ}

\begin{abstract}
Во чест на големиот придонес направен од страна на академик Глигор Јовановски на полето на минералогијата во Македонија, овој труд ја промовира потенцијалната улога што можат да ја имаат минералите како инспирација за идентификување нови материјали како извори за одржливо складирање на енергија воопшто, и особено за развој на литиумските батерии. Ова го докажуваме со индикација на иновативна употреба на полианјони во нови катодни материјали на Li-joнски батерии, како што се на пример оливин литиумжелезен фосфат $\left(\mathrm{LiFePO}_{4}\right)$, и еден уште понов

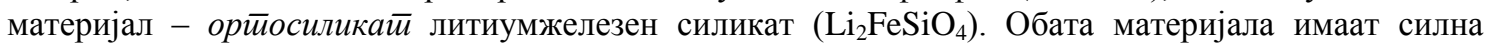
внатрешна врска со минералогијата - и добро илустрираат каква улога минералогијата може да има за продор на нови материјали во ова, но и во други подрачја на модерната технологија.
\end{abstract}

Клучни зборови: минерали; Li-joн батерии; електроди; катоди

\section{INTRODUCTION}

In spite of their inorganic and essentially inanimate nature, minerals lie at the very core of our search today for materials which can promote technological breakthroughs in many areas, not least in the context of the needs of our modern society in the area of sustainable energy generation and storage. The most obvious examples appear in our hunt for new materials for solar-cell, battery, fuel-cell and supermagnet materials. We draw special attention here to the potential role of minerals as a source of inspiration in these endeavors, while - at the same time - we pay tribute to the key role played by Professor Jovanovski in documenting the wealth of natural resources still waiting to be exploited in the rich mineral deposits within the borders of Macedonia [1]. We demonstrate this potential through our on-going search worldwide for novel materials for energy

- Dedicated to Academician Gligor Jovanovski on the occasion of his $70^{\text {th }}$ birthday. 
storage and conversion applications - especially in the field of next-generation Li-ion battery technologies; see [2].

\section{ENERGY STORAGE AND CONVERSION MATERIALS}

"Earth, air, fire, water" - these were believed by the Ancient Greeks to be the basic building blocks (elements) of their World [3]. Seen in today's perspective, "air, fire, water" correspond to the essential material components in electrochemical energy conversion devices now known as fuel-cells, while the fourth element "earth" (read: the mineral content of the Earth's crust) is the source of active electrode materials in advanced battery concepts, which are today proving so relevant to the development of next-generation sustainable transport and communication solutions. As our global population continues to grow and become more mobile, the reduction of Greenhouse Gas (GHG) emissions from the transport sector presents an ever more urgent challenge. They are currently responsible for roughly one third of the World's total GHG emissions [4]. The development of on-board storage of electrical energy derived from sustainable power sources in cheap, large-scale batteries is slowly emerging as a critical element of many long-term solutions. However, an efficient battery technology capable of meeting this challenge is still lacking to a large extent, mainly because of performance inadequacies in terms of energy- and powerdensity, safety, etc. Above all, their high cost can be seen as the major hinder holding back largescale battery development. Although we have seen significant breakthroughs in recent years, these must be consolidated if we are to achieve commercially realistic sustainable solutions. It is already clear that rechargeable Li-ion batteries (as already used widely in mobile-phones and portable computers) are also fast becoming the battery of choice in next-generation hybrid and pure-electric (HEV, P-HEV and EV) vehicle concepts, as well as in large-scale sustainable energy storage applications. No other battery technology has yet to emerge to pose a serious challenge. As everlarger Li-ion battery packs are developed, we will be forced to exploit significantly cheaper cathode materials - with the cost of the cathode material corresponding to more than one-third of the total material costs in a Li-ion battery. Huge savings can be made if the cost of cathode materials can be reduced; so the question arises: can significant breakthroughs be found amongst as yet unexploited minerals? It has become increasingly clear that the ultimate solution within available battery (electro)chemistries must be based on the cheapest and most abundant transition-metal - iron $(\mathrm{Fe})$ - in combination with a graphite $(\mathrm{C})$ or silicon ( $\mathrm{Si}$ ) anode. Iron $(\mathrm{Fe})$ is the only truly cheap transition-metal, so iron-based cathodes have recently come to dominate much of the current research effort in the area of large-scale $\mathrm{Li}$-ion battery development [5].

\section{Fe-BASED Li-ION BATTERY ELECTRODE MATERIALS}

Pioneering work by Thackeray et al. [6] in the early 1980 s demonstrated the feasibility of electrochemically inserting lithium into magnetite $\left(\mathrm{Fe}_{3} \mathrm{O}_{4}\right)$ and hematite $\left(\mathrm{Fe}_{2} \mathrm{O}_{3}\right)$. Despite the fact that the electrochemical potential of iron oxides is too low for practical cathode materials $(<2 \mathrm{~V})$, the foundations for the development of one of the most important cathode materials - the manganese spinel $\mathrm{LiMn}_{2} \mathrm{O}_{4}$ [7] - had been laid (Fig. 1). More recently, however, the reversible conversion of hematite into nanosize metallic iron has also revived interest in developing high-capacity and low-cost Fe-based anode materials for "green" Liand Na-ion battery applications [8].

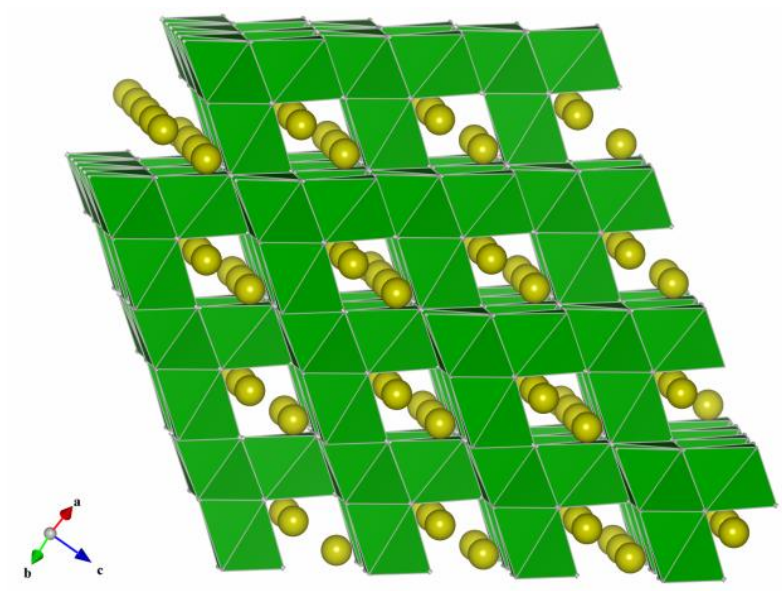

Fig. 1. The structure of spinel $\mathrm{AB}_{2} \mathrm{O}_{4}$ (magnetite, hausmannite) shown for the $\mathrm{Li}$-insertion material $\mathrm{LiMn}_{2} \mathrm{O}_{4}$, with $\mathrm{Mn}$ octahedral coordination (green) and Li-ions (yellow). $\mathrm{LiMn}_{2} \mathrm{O}_{4}$ spinel can be synthesized in a simple solid state reaction of hausmannite $\left(\mathrm{Mn}_{3} \mathrm{O}_{4}\right)$ and zabuyelite $\left(\mathrm{Li}_{2} \mathrm{CO}_{3}\right)$, and provides a facile, three-dimensional network for $\mathrm{Li}$-ion diffusion.

A major breakthrough for Fe-containing Liion battery cathodes came with the demonstration of electrochemical activity in the olivine structure lithium iron phosphate $\left(\mathrm{LiFePO}_{4}\right)[9,10]$; a mate- 
rial occurring naturally as triphylite in pegmatite deposits, converting to heterosite following the electrochemical extraction of lithium [11-13].

$\mathrm{LiFePO}_{4}$ satisfies many of the demands which can be placed on a potential cathode material for large-scale Li-ion battery applications. Its strong covalent $\mathrm{P}-\mathrm{O}$ bonds ensure electrochemical stability within a voltage range, where only a minimal surface film (the so-called SEI layer) is formed on cell cycling [14]. $\mathrm{LiFePO}_{4}$ is also "green" and relatively cheap. Its main drawback is its low electronic conductivity $\left(c a .10^{-9} \mathrm{~S} \mathrm{~cm}^{-1}\right.$ at room temperature), but the negative consequences of this have been minimized by reducing the effective conduction path length, e.g., by preparing nano-size or nano-porous particles [15.16], and/or by coating the active particles with a thin electronically conducting layer (generally carbon) [17]. One serious problem still remains, however: its theoretical gravitometric capacity is still only $c a .170$ $\mathrm{mAh} / \mathrm{g}$, resulting in a $15-20 \%$ lower energy density compared to that of the standard mobile-phone battery cathode material $\mathrm{LiCoO}_{2}$ [18]. Improvements on $\mathrm{LiFePO}_{4}$ have been sought intensively, and one of the more popular family of materials under current focus is the neso- or orthosilicates (from the Greek $v \eta \sigma o \varsigma$ (nesos): island); typically, the iron silicate system $\mathrm{Li}_{2} \mathrm{FeSiO}_{4}$ [19-24]. Its structure resembles closely that of the $\mathrm{LiFePO}_{4}$ olivine system, comprising isolated $\mathrm{SiO}_{4}$ tetrahedra as occurring in the archetypal olivine $(\mathrm{Fe}, \mathrm{Mg})_{2} \mathrm{SiO}_{4}$, see Figure 2 . It has many clear advantages over existing materials; see Table 1:

- It is cheap - potentially even cheaper than the phosphate derivatives - with iron and silicon oxides making up $>10 \%$ of the Earth's crust!

- Its two-dimensional network for Li-ion diffusion makes it less prone to conduction pathway blockage and performance degradation due to impurities, as occurs in one-dimensional channel materials like $\mathrm{LiFePO}_{4}$ [25]; this further reduces its preparation costs since cheaper, less pure reactants can be used.

- It is an essentially "green" material with virtually no direct environmental hazards compared to cobalt-based cathodes, $c f$. $\mathrm{LiCoO}_{2}$.

- It has been shown to compare favourably in terms of its mechanical, chemical and electrochemical properties with other candidate cathodes, and cycles well with low capacity loss.

- It can also be prepared by a variety of synthetic techniques within the micro- and nano-range of particle sizes necessary to combat the persisting problem of low electronic conductivity.

- As for $\mathrm{LiFePO}_{4}$, nano-coating facilitates the electronic wiring of the active cathode particles to the current collector, where we can again expect to have to make the same type of trade-off between amount of carbon used and improved electronic conductivity.

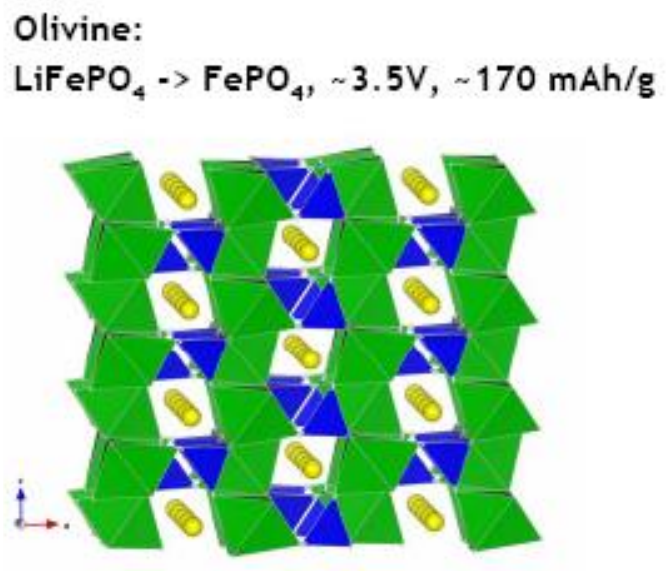

\section{Orthosilicate: \\ $\mathrm{Li}_{2} \mathrm{FeSiO}_{4} \rightarrow \mathrm{LiFeSiO}_{4}, \sim 2.85 \mathrm{~V}, \sim 170 \mathrm{mAh} / \mathrm{g}$}

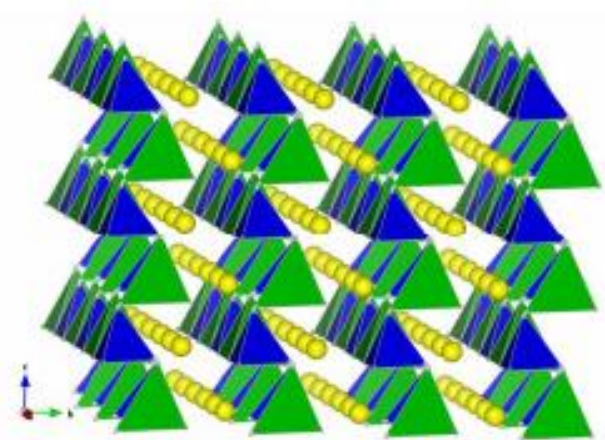

Fig. 2. A comparison of the $\mathrm{LiFePO}_{4}$ (olivine) and $\mathrm{Li}_{2} \mathrm{FeSiO}_{4}$ (orthosilicate) structures; the latter clearly exhibits a significantly higher concentration of lithium ions and more available ion-diffusion pathways

However, the theoretical capacity of $\mathrm{Li}_{2} \mathrm{FeSiO}_{4}$ is still an unimpressive $170 \mathrm{mAh} / \mathrm{g}$ which, combined with its relatively low voltage (only ca. $2.8 \mathrm{~V}$ after the first cycle; see Fig. 3), results in an available energy density of only 480 $\mathrm{Wh} / \mathrm{kg}$. However, $\mathrm{Li}_{2} \mathrm{FeSiO}_{4}$ still has one obvious feature to recommend it: it contains two $\mathrm{Li}$ atoms per $\mathrm{Fe}$ atom in the formula unit, thus giving the promise of a revolutionary 2-electron redox reaction in a Li-ion battery. Since Fe will realistically only pass between $\mathrm{Fe}^{2+}$ and $\mathrm{Fe}^{3+}$, substitution by some other transition-metal (TM) ion $\mathrm{X}$ which can 
undergo $\mathrm{X}^{2+} \Rightarrow \mathrm{X}^{3+} \Rightarrow \mathrm{X}^{4+}$ transitions is needed to facilitate the removal of $\left(2 \mathrm{Li}^{+}+2 \mathrm{e}^{-}\right)$, with an accompanying increase in capacity.

\section{Table 1}

A comparison of battery-related performance parameters for $\mathrm{LiFePO}_{4}$ - and $\mathrm{Li}_{2} \mathrm{FeSiO}_{4}$-based Li-ion batteries

\begin{tabular}{lcc}
\hline \hline & $\mathrm{LiFePO}_{4}$ & $\mathrm{Li}_{2} \mathrm{FeSiO}_{4}$ \\
\hline Cell potential (V) & $\underline{3.4}$ & 2.8 \\
Theoretical capacity (mAh/g) & 166 & 167 \\
Energy density (Wh/l) & $\underline{270}$ & 235 \\
Cost (for large volumes) & medium & $\underline{\mathrm{low}}$ \\
Life-time & ++ & ++ \\
Safety & ++ & ++ \\
Environment & ++ & ++ \\
\hline \hline
\end{tabular}

Note: A compromise must be reached between the higher voltage and energy density of $\mathrm{LiFePO}_{4}$ and the potentially lower cost of $\mathrm{Li}_{2} \mathrm{FeSiO}_{4}$.

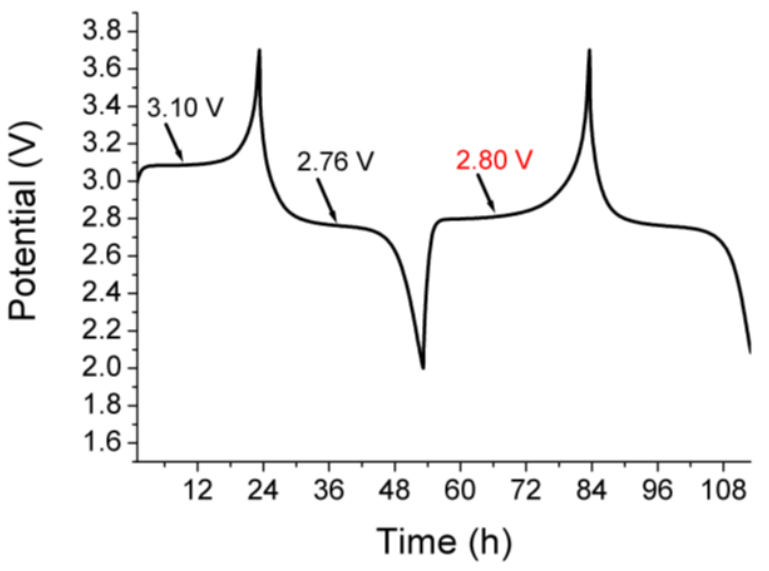

Fig. 3. The first and second charge/discharge cycles for pristine $\mathrm{Li}_{2} \mathrm{FeSiO}_{4}$, cycled at $60{ }^{\circ} \mathrm{C}$ and $\mathrm{C} / 25$ rate, showing a drop in voltage from 3.1 to $2.8 \mathrm{~V}$ [21]

Manganese is the obvious choice since its $3^{+}$ and $4^{+}$redox states are close in energy, and its relative abundance still renders it a cheap and sustainable material. The cathode reaction for the mixed-ion system $\mathrm{Li}_{2}\left(\mathrm{Fe}_{1-\mathrm{x}} \mathrm{Mn}_{\mathrm{x}}\right) \mathrm{SiO}_{4}$ (as illustrated schematically in Figure 4 for the case of $x=0.5$ ) thus becomes:

$$
\begin{gathered}
\mathrm{Li}_{2}{ }_{2}\left(\mathrm{Fe}^{2+}{ }_{1-\mathrm{x}} \mathrm{Mn}^{2+}{ }_{\mathrm{x}}\right) \mathrm{SiO}_{4} \Rightarrow \mathrm{Li}^{+}{ }_{1-\mathrm{x}}\left(\mathrm{Fe}^{3+}{ }_{1-\mathrm{x}} \mathrm{Mn}^{4+}{ }_{\mathrm{x}}\right) \mathrm{SiO}_{4} \\
+(\mathbf{1 + x}) \mathbf{L i}^{+}+(\mathbf{1 + x}) \mathbf{e}^{-}
\end{gathered}
$$

The theoretical capacity would thus increase dramatically from $170 \mathrm{~mA} \mathrm{~h} / \mathrm{g}$ to $255 \mathrm{~mA} \mathrm{~h} / \mathrm{g}$.

Experimental studies have later shown that, although the hoped for $\mathrm{Mn}^{2+} \Rightarrow \mathrm{Mn}^{3+} \Rightarrow \mathrm{Mn}^{4+}$ transitions actually appear to occur on charging (with an accompanying increase in first-cycle capacity), the voltage curve observed on the subsequent reduction cycle has a marked hysteresis, suggesting some structural reorganization [26]. Consistent multiple cycling has yet to be demonstrated reliably - but there are lessons to be learnt from the successful activation of $\mathrm{Mn}$ in other candidate materials, especially in $\mathrm{LiMn}_{2} \mathrm{O}_{4}$ spinel. Needless to say, if we are successful in making this type of substitution in $\mathrm{Li}_{2} \mathrm{FeSiO}_{4}$ - or, indeed, in any other as yet undiscovered Fe-based silicate host (thereby facilitating a true "2-electron redox reaction" in a Li-ion battery cathode materials) - the implications for $\mathrm{HEV} / \mathrm{P}-\mathrm{HEV} / \mathrm{EV}$ and sustainable energy storage applications will be far reaching for our planet.

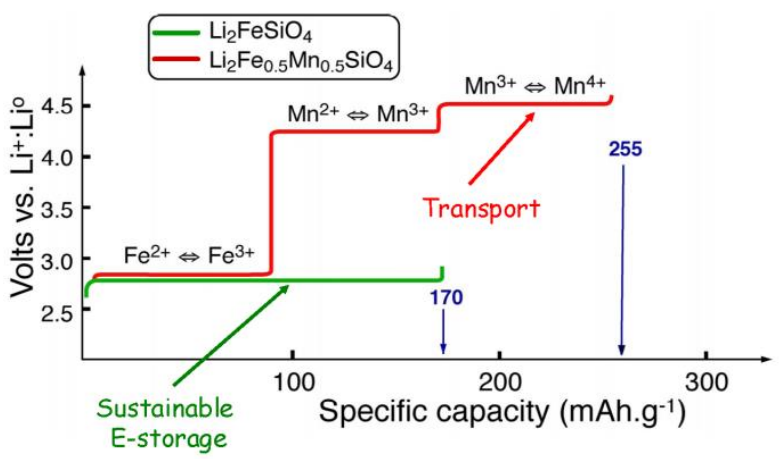

Fig. 4. A schematic illustration of the effect on the charging curve for $\mathrm{Li}_{2} \mathrm{FeSiO}_{4}$ (green line) of $50 \%$ substitution of $\mathrm{Fe}$ by $\mathrm{Mn}$ in its orthosilicate structure (red line).

\section{CONCLUDING REMARK}

As stated at the outset, this paper is intended merely to draw attention to the important role that minerals can have as a source of inspiration in our continued search for material-based breakthroughs within a wide range of modern industrial applications - not least in the area of electrochemical energy storage.

Acknowledgements. The ideas presented here emerge from experiences gained within research projects supported by the Global Climate and Energy Project of Stanford (GCEP), the Swedish Energy Agency (STEM), VINNOVA and the Swedish Science Research Council (VR).

\section{REFERENCES}

[1] G. Jovanovski, B. Boev, P. Makreski, Minerals from the Republic of Macedonia, Macedonian Academy of Sciences and Arts, Skopje, 2012.

[2] M. M. Thackeray, From gems to lithium battery electrodes: the significance of the diamond, ruby (sapphire), spinel and peridot structures, J. Power Sources, 97-98, 7-12 (2001).

[3] Plato, Timaeus, 48b. 
[4] S. F. Tie, C. W. Tan, A review of energy sources and energy management systems in electric vehicles, Renew. Sust. Energy Rev., 20, 82-102 (2013).

[5] A. Yamada, Iron-based materials strategies, MRS Bulletin, 39, 423-428 (2014).

[6] M. M. Thackeray, W. I. F. David, J. B. Goodenough, Structural characterization of the lithiated iron oxides $\mathrm{Li}_{\mathrm{x}} \mathrm{Fe}_{3} \mathrm{O}_{4}$ and $\mathrm{Li}_{\mathrm{x}} \mathrm{Fe}_{2} \mathrm{O}_{3}(0<\mathrm{x}<2)$, Mat. Res. Bull., 17, 785-793 (1982).

[7] M. M. Thackeray, P. J. Johnson, L. A. de Picciotto, P. G. Bruce, J. B. Goodenough, Electrochemical extraction of lithium from $\mathrm{LiMn}_{2} \mathrm{O}_{4}$, Mat. Res. Bull., 19, 179-187 (1984).

[8] M. Valvo, F. Lindgren, U. Lafont, F. Björefors, K. Edström, Towards more sustainable negative electrodes in Na-ion batteries via nanostructured iron oxide, $J$. Power Sources, 245, 967-978 (2014).

[9] A. K. Padhi, K. S. Nanjundaswamy, J. B. Goodenough, Phospho-olivines as positive-electrode materials for rechargeable lithium batteries, J. Electrochem. Soc., 144, 1188-1194 (1997).

[10] A. S. Andersson, J. O. Thomas, B. Kalska, L. Häggström, Thermal stability of $\mathrm{LiFePO}_{4}$-based cathodes, Electrochem. Solid-State Letts., 3, 66-68 (2000).

[11] N. Ravet, Y. Chouinard, J. F. Magnan, S. Besner, M. Gauthier, M. Armand, Electroactivity of natural and syntetic triphylite, J. Power Sources, 97-98, 503-507 (2001).

[12] A. M. Fransolet, D. Antenucci, J. M. Speetjens, P. Tarte, An X-ray determinative method for the divalent-cation ratio in the triphylite-lithiophilite series, Mineral. Mag., 48, 373-381 (1984).

[13] A. M. Fransolet, The phosphate mineral associations of the Tsaobismund pegmatite, Namibia, Contrib. Mineral. Petrol., 92, 502-517 (1986).

[14] M. Herstedt, M. Stjerndahl, A. Nytén, T. Gustafsson, H. Rensmo, H. Siegbahn, N. Ravet, M. Armand, J. O. Thomas, K. Edström, Surface chemistry of carbontreated $\mathrm{LiFePO}_{4}$ particles for Li-ion battery cathodes studied by PES, Electrochem. Solid-State Letts., 6, A202-A206 (2003).

[15] H. Huang, S. C. Yin, L. F. Nazar, Approaching theoretical capacity of $\mathrm{LiFePO}_{4}$ at room temperature at high rates. Electrochem. Solid-State Letts., 4, A170A172 (2001).

[16] Z. H. Chen, J. R. Dahn, Reducing carbon in $\mathrm{LiFePO}_{4} / \mathrm{C}$ composite electrodes to maximize specific energy, volumetric energy, and tap density, J. Electrochem. Soc., 149, A1184-A1189 (2002).

[17] N. Ravet, J. B. Goodenough, S. Besner, M. Simoneau, P. Hovington, M. Armand, Improved iron based cathode material, Abstract \#127, $196^{\text {th }}$ ECS Meeting, Hawaii, 17-22 October 1999.

[18] K. Mizushima, P. C. Jones, P. J. Wiseman, J. B. Goodenough, $\mathrm{Li}_{\mathrm{x}} \mathrm{CoO}_{2}(0<\mathrm{x}<1)-\mathrm{a}$ new cathode material for batteries of high-energy density, Mat. Res. Bull., 15, 783-789 (1980).

[19] P. Tarte, R. Cahay, Synthesis and structure of a new series of $\mathrm{Li}_{2} \mathrm{X}(\mathrm{II}) \mathrm{GeO}_{4}$ and $\mathrm{Li}_{2} \mathrm{X}(\mathrm{II}) \mathrm{SiO}_{4}$ structurally related to $\mathrm{Li}_{3} \mathrm{PO}_{4}$, C. R. Acad. Sci. Paris, 139C, 777 (1970).

[20] B. Monnaye, C. Carrault, G. Perez, R. Bouaziz, Family of double lithium orthogermanates - crystal-structure of $\mathrm{Li}_{2} \mathrm{MgGeO}_{4}$, C. R. Acad. Sci. Paris, 278C, 251-253 (1974).

[21] A. Nytén, A. Abouimrane, M. Armand, T. Gustafsson, J. O. Thomas, Electrochemical performance of $\mathrm{Li}_{2} \mathrm{FeSiO}_{4}$ as a new Li-battery cathode material. Electrochem. Comm., 7, 156-160 (2005).

[22] A. Nytén, S. Kamali, L. Häggström, T. Gustafsson, J. O. Thomas, The lithium extraction/insertion mechanism in $\mathrm{Li}_{2} \mathrm{FeSiO}_{4}$, J. Mater. Chem., 16, 2266-2272 (2006)

[23] A. Nytén, M. Stjerndahl, H. Rensmo, H. Siegbahn, M. Armand, T. Gustafsson, K. Edström, J. O. Thomas, Surface characterization and stability phenomena in $\mathrm{Li}_{2} \mathrm{FeSiO}_{4}$ studied by PES/XPS, J. Mater. Chem., 16, 3483-3488 (2006).

[24] R. Dominko, M. Bele, M. Gaberšček, A. Meden, M. Remškar, J. Jamnik, Structure and electrochemical performance of $\mathrm{Li}_{2} \mathrm{MnSiO}_{4}$ and $\mathrm{Li}_{2} \mathrm{FeSiO}_{4}$ as potential Li-battery cathode materials, Electrochem. Comm., 8, 217-222 (2006).

[25] A. Liivat, J. O. Thomas, Solid State Ionics, 192, 58-64 (2011).

[26] A. Kokalj, R. Dominko, G. Mali, A. Meden, M. Gaberscek, J. Jamnik, Beyond one-electron reaction in $\mathrm{Li}$ cathode materials: designing $\mathrm{Li}_{2} \mathrm{Mn}_{\mathrm{x}} \mathrm{Fe}_{1-\mathrm{x}} \mathrm{SiO}_{4}$, Chem. Mater, 19, 3633-3640 (2007). 
